\title{
Isopiestic Determination of the Activity of Water in Aqueous Sulfuric Acid-Sulfate Systems
}

\author{
Tatsuhiko Michimoto*, Yasuhiro AwAKURA*, and Hiroshi MAJIMA*
}

\begin{abstract}
The activities of water in the systems $\mathrm{H}_{2} \mathrm{SO}_{4}-\mathrm{MgSO}_{4}-\mathrm{H}_{2} \mathrm{O}, \mathrm{H}_{2} \mathrm{SO}_{4}-\mathrm{Na}_{2} \mathrm{SO}_{4}-\mathrm{H}_{2} \mathrm{O}$, and $\mathrm{H}_{2} \mathrm{SO}_{4}-\mathrm{Li}_{2} \mathrm{SO}_{4}-$ $\mathrm{H}_{2} \mathrm{O}$ were determined by an isopiestic method at $298 \mathrm{~K}$. The applicability of the Zdanovskii rule to these solution systems was examined. Although some deviation from the Zdanovskii rule was observed for the solution containing $\mathrm{Na}_{2} \mathrm{SO}_{4}$ and $\mathrm{Li}_{2} \mathrm{SO}_{4}$, the agreement between the evaluated and the experimental values is reasonable. The Robinson and Bower additive rule was also found to be applicable to evalunte the water activities for the solution systems studied in this work.
\end{abstract}

\section{Introduction}

There are many processes in which concentrated sulfuric acid solutions and sulfuric acidsulfate mixed soluitons are used as reaction media. It is important to know the activities of the solutes for precise understanding of reactions which may proceed in these solutions. At the same time, information on the activities of water in the solutions is indispensable.

Stokes and Robinson pointed out the importance of the activity of water in the study of concentrated salt solutions ${ }^{1)}$. Generally we can assume that the activity of water is unity in a dilute aqueous electrolyte solution, but this is certainly not the case for concentrated solutions. For example, it is reported that the activity of water in $3 \mathrm{~mol} \cdot \mathrm{kg}^{-1} \mathrm{H}_{2} \mathrm{SO}_{4}$ solution is 0.852 at $298 \mathrm{~K}^{23}$.

The activities of water in a variety of electrolyte solution systems have been reported and compiled in a data book ${ }^{3}$. But there are few data on the activity of water in solution systems containing two or more electrolytes, although such data are useful in the determination of the activities of the solute species in the solutions.

In this study, the authors measured the activities of water in $\mathrm{H}_{2} \mathrm{SO}_{4}-\mathrm{MgSO}_{4}-\mathrm{H}_{2} \mathrm{O}, \mathrm{H}_{2} \mathrm{SO}_{4}$ $\mathrm{Na}_{2} \mathrm{SO}_{4}-\mathrm{H}_{2} \mathrm{O}$ and $\mathrm{H}_{2} \mathrm{SO}_{4}-\mathrm{Li}_{2} \mathrm{SO}_{4}-\mathrm{H}_{2} \mathrm{O}$ solutions.

\section{Experimental Procedures}

In this study, the activities of water in sulfuric acid-sulfate mixed solutions were determined by

* Department of Metallurgy, Kyoto University (Sakyoku, Kyoto 606)

Key Words: Water Activity, Isopiestic Method, Sulfuric Acid System an isopiestic method". This method requires a reference solution for which a relationship between the composition of the solution and the vapour pressure of the solution is well established. The reference solutions used in this work included a sulfuric acid solution and a sulfate solution. When a test solution containing sulfuric acid and sulfate is placed in a closed vessel together with the reference solution, the difference in the vapour pressure between both solutions causes the transport of water via the gas phase from one solution to the other. This transport proceeds until both vapour pressures reach the same level. By analyzing the concentrations of both test and reference solutions after equilibrium is attained, we can determine the relationship between the concentration and the equilibrium vapour pressure of the test solution from the information on the vapour pressure of the reference solution. The activity of water in the test solution can be estimated as the ratio of the vapour pressure of the test solution to the vapour pressure of the pure water at the same temperature and pressure. Therefore, the standard state of water activity thus determined is the pure water.

The apparatus used for the isopiestic method in this work was essentially the same as that reported by Kirgintsev and Lukyanov ${ }^{4}$. As is shown in Fig. 1, the apparatus consists of a glass cylinder closed at the top and bottom with stainless steel discs. The top disc carries a propeller type stirrer with electromagnetic-induced transmission drive which permits the gas phase in the apparatus to be agitated without breaking the seal. The glass cylinder is sealed 


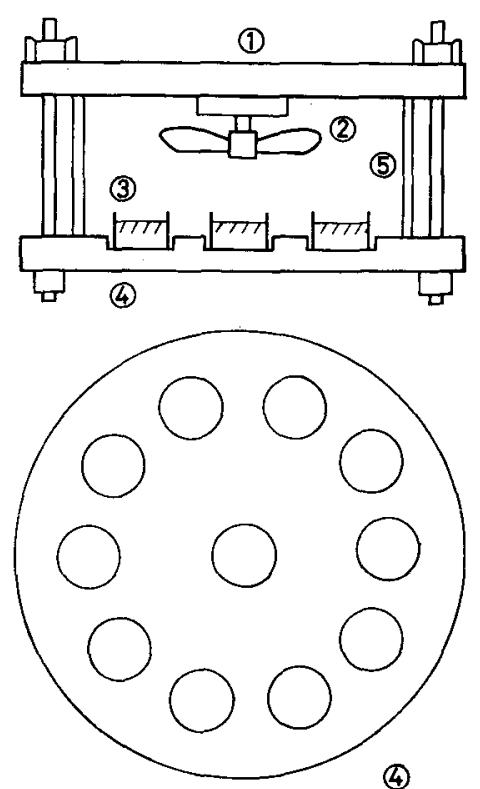

Fig. 1 Apparatus used for the isopiestic method

1: Top disc made of stainless steel, 2 : Propellertype stirrer with electro-magnetic transmission drive, $3:$ Glass cuvette, $4:$ Bottom disc made of stainless steel, $5:$ Glass cylinder

by means of rubber gaskets between the cylinder and the top and bottom dises. The bottom dise has sockets to hold 11 cuvettes. Glass cups of $25 \mathrm{~mm}$ diameter and $10 \mathrm{~mm}$ depth were used as the cuvettes. Approximately $1 \mathrm{~cm}^{3}$ of the test solution or reference solution is placed in the cuvette. In this work, 3 among 11 cuvettes located at triangular positions were used for the reference solutions. The remaining 8 cuvettes were for the test solutions, which were the mixtures of sulfuric acid, sulfate and water.

In order to reduce the time required to achieve equilibrium, the composition of each solution placed in the cuvettes was adjusted on the basis of the estimation by the Zdanovskii rule, so that the vapour pressure of the solutions were at approximately the same level.

The vessel was sealed and completely immersed in a water bath thermostated at $(298 \pm$ $0.1) \mathrm{K}$ for two weeks. During this period, the gas phase in the vessel was agitated by the stirrer. Since the mass of non-volatile electrolyte in each test solution was known, it was possible to determine the compositions of elec- trolytes of the test and reference solutions after the equilibrium by weighing.

All the chemicals used in this study were of reagent grade. For the preparation of all the solutions, de-ionized water with the resistivity of above $5 \times 10^{6} \Omega \cdot \mathrm{cm}$ from an ion-exchange column was used. Stock solutions of sulfuric acid and sulfates were prepared and the molalities of solutions were determined by the density measurement. Each test solution of about $100 \mathrm{~cm}^{3}$ was prepared by mixing the de-ionized water with stock solutions of sulfuric acid and sulfate by using a buret just before each experiment. The molalities of sulfuric acid and sulfate in the test solution were determined by calculation from the volume and molality of each stock solution and the volume of the deionized water added.

\section{Experimental Results}

Prior to the determination of the activity of water in the $\mathrm{H}_{2} \mathrm{SO}_{4}$ solutions, the uniformity of temperature in the apparatus was examined. For this purpose, 11 cuvettes containing sulfuric acid solutions of the same concentration were placed in the sealed vessel, and the vessel was kept in the water bath at $298 \mathrm{~K}$ for 7 days. Then, the molality of sulfuric acid in each cuvettes was determined. The results are shown in Table 1. Cuvette No. 11 was placed on the

Table 1 Examination of the uniformity of temprature in the sealed vessel

\begin{tabular}{c|c}
\hline Cuvette No. & $m\left(\mathrm{H}_{2} \mathrm{SO}_{4}\right) \overline{\mathrm{mol}} \cdot \overline{\mathrm{kg}^{-1}}$ \\
\hline 1 & 0.1306 \\
2 & 0.1309 \\
3 & 0.1310 \\
4 & 0.1309 \\
5 & 0.1308 \\
6 & 0.1314 \\
7 & 0.1308 \\
8 & 0.1307 \\
9 & 0.1309 \\
10 & 0.1307 \\
11 & 0.1308 \\
\hline
\end{tabular}

center of the bottom disk, and the other 10 cuvettes were placed clockwise in the outer sockets. The relative difference between the 
maximum and minimum molalities was $0.6 \%$. Also, the $\mathrm{H}_{2} \mathrm{SO}_{4}$ molality of the 11 cuvettes did not show any significant deviation depending on the location of the cuvette.

The time required for the achievement of equilibrium was examined. Sulfuric acid solutions whose $\mathrm{H}_{2} \mathrm{SO}_{4}$ molarilies ranged from 0.38 to $0.65 \mathrm{~mol} \cdot \mathrm{kg}^{-1}$ were used for this experiment. The results are shown in Fig. 2. After 2 weeks, the $\mathrm{H}_{2} \mathrm{SO}_{4}$ molality of all the test solutions reached a constant level of $0.51 \mathrm{~mol} \cdot \mathrm{kg}^{-1}$.

In each run, we took an average of the activities of the three reference solutions as the activity of water at equilibrium. Table 2 shows the activities of water of the reference solutions in each run before and after 2 weeks obtained for the solution system $\mathrm{H}_{2} \mathrm{SO}_{4}-\mathrm{Li}_{2} \mathrm{SO}_{4}-\mathrm{H}_{2} \mathrm{O}$ at $298 \mathrm{~K}$. The average value of the relative difference of $a\left(\mathrm{H}_{2} \mathrm{O}\right)$ of those solutions after 2 weeks was found to be $0.119 \%$. On the other hand, the avarage values for the solution systems $\mathrm{H}_{2} \mathrm{SO}_{4}-\mathrm{MgSO}_{4}-\mathrm{H}_{2} \mathrm{O}$ and $\mathrm{H}_{2} \mathrm{SO}_{4}-\mathrm{Na}_{2} \mathrm{SO}_{4}-\mathrm{H}_{2} \mathrm{O}$ were $0.229 \%$ and $0.149 \%$, respectively. These results suggest that the relative precision of the water activities determind in this work was approximately $0.3 \%$.

In this work, we have usually used the reference solutions whose water activities are almost

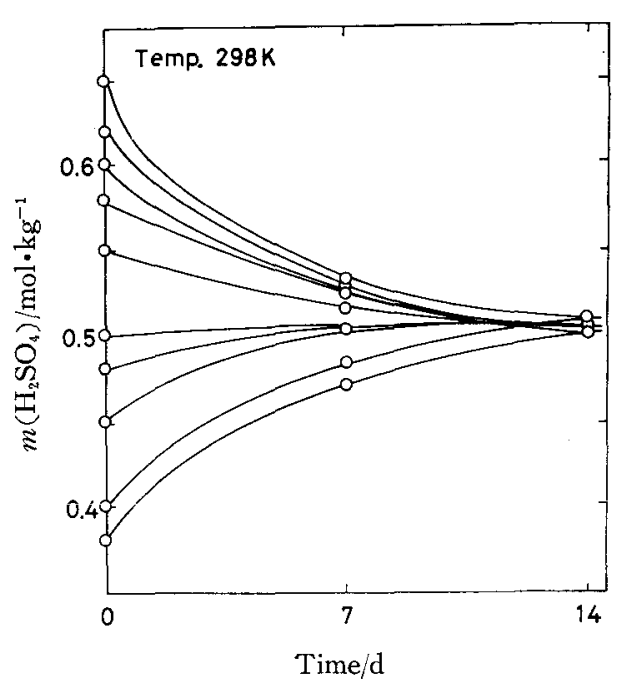

Fig. 2 Time variation of molality for aqueous sulfuric acid solutions during the holding period in the sealed vessel at $298 \mathrm{~K}$

the same, and the compositions of the test solutions were adjusted so as to have nearly the same water activity according to the Zdanovskii as mentioned earlier. When the initial compositions of the test solutions were chosen in this way, the reference solutions and the test solutions with the compositions similar to that of

Table 2 Accuracy of the activity of water determined by the isopiestic method for $\mathrm{H}_{2} \mathrm{SO}_{4}-\mathrm{Li}_{2} \mathrm{SO}_{4}-\mathrm{H}_{2} \mathrm{O}$ solutions at $298 \mathrm{~K}$

(Figures shown at upper and lower lines indicate the activity of water before and after the experiment for 2 weeks, respectively)

\begin{tabular}{|c|c|c|c|c|c|}
\hline \multirow[b]{2}{*}{ Exp. No. } & \multicolumn{3}{|c|}{$a\left(\mathrm{H}_{2} \mathrm{O}\right)$} & \multirow[b]{2}{*}{$\triangle a\left(\mathrm{H}_{2} \mathrm{O}\right) / \%$} & \multirow[b]{2}{*}{$\overline{a\left(\mathrm{H}_{2} \mathrm{O}\right)}$} \\
\hline & $\begin{array}{c}\text { Standard } \\
\text { Soln. No. } 1 \\
\mathrm{H}_{2} \mathrm{SO}_{4}\end{array}$ & $\begin{array}{l}\text { Standard } \\
\text { Soln. No. } 1 \\
\mathrm{H}_{2} \mathrm{SO}_{4}\end{array}$ & $\begin{array}{l}\text { Standard } \\
\text { Soln. No. } 1 \\
\mathrm{Li}_{2} \mathrm{SO}_{4}\end{array}$ & & \\
\hline 13 & $\begin{array}{l}0.9796 \\
0.9793\end{array}$ & $\begin{array}{l}0.9797 \\
0.9796\end{array}$ & $\begin{array}{l}0.9795 \\
0.9798\end{array}$ & $\begin{array}{l}0.020 \\
0.051\end{array}$ & 0.9796 \\
\hline 14 & $\begin{array}{l}0.9694 \\
0.9695\end{array}$ & $\begin{array}{l}0.9686 \\
0.9695\end{array}$ & $\begin{array}{l}0.9695 \\
0.9699\end{array}$ & $\begin{array}{l}0.093 \\
0.041\end{array}$ & 0.9696 \\
\hline 15 & $\begin{array}{l}0.9591 \\
0.9591\end{array}$ & $\begin{array}{l}0.9573 \\
0.9591\end{array}$ & $\begin{array}{l}0.9605 \\
0.9601\end{array}$ & $\begin{array}{l}0.334 \\
0.104\end{array}$ & 0.9594 \\
\hline 16 & $\begin{array}{l}0.9510 \\
0.9505\end{array}$ & $\begin{array}{l}0.9500 \\
0.9506\end{array}$ & $\begin{array}{l}0.9507 \\
0.9508\end{array}$ & $\begin{array}{l}0.105 \\
0.032\end{array}$ & 0.9506 \\
\hline 17 & $\begin{array}{l}0.9416 \\
0.9420\end{array}$ & $\begin{array}{l}0.9406 \\
0.9407\end{array}$ & $\begin{array}{l}0.9404 \\
0.9414\end{array}$ & $\begin{array}{l}0.128 \\
0.138\end{array}$ & 0.9414 \\
\hline 18 & $\begin{array}{l}0.9318 \\
0.9320\end{array}$ & $\begin{array}{l}0.9289 \\
0.9320\end{array}$ & $\begin{array}{l}0.9308 \\
0.9309\end{array}$ & $\begin{array}{l}0.215 \\
0.118\end{array}$ & 0.9316 \\
\hline 19 & $\begin{array}{l}0.9214 \\
0.9230\end{array}$ & $\begin{array}{l}0.9204 \\
0.9226\end{array}$ & $\begin{array}{l}0.9209 \\
0.9199\end{array}$ & $\begin{array}{l}0.109 \\
0.337\end{array}$ & 0.9218 \\
\hline & & & $\overline{\triangle a}\left(\mathrm{H}_{2} \mathrm{O}\right)$ & 0.119 & \\
\hline
\end{tabular}


the reference solution were normally diluted during the 2 weeks holding period, but the test solutions containing both sulfuric acid and sulfate at almost the same molalities were concentrated by the transport of water via the gas phase. Some additional experiments in which the transport of water was made to occur in the reverse direction were curried out in order to examine the effect of the composition of the starting test solution on the activity of water. Figure 3 shows typical examples of the results

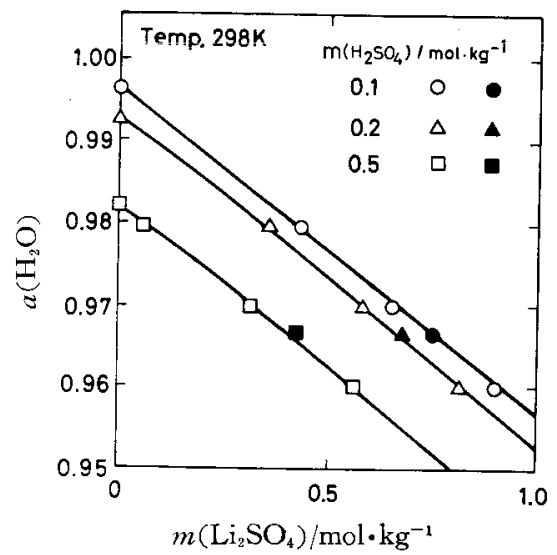

Fig. 3 A typical example of the effect of the composition of the starting solution in the system $\mathrm{H}_{2} \mathrm{SO}_{4}-\mathrm{Li}_{2} \mathrm{SO}_{4}-\mathrm{H}_{2} \mathrm{O}$ on the activity of water determined by the isopiestic method at $298 \mathrm{~K}$

$O \triangle \square$ : Starting from the composition estimated from Zdanovskii rule

410 : Starting from the composition having a larger positive deviation from Zdanovskii rule

of these comparative experiments for the $\mathrm{H}_{2} \mathrm{SO}_{4}$ $\mathrm{Li}_{2} \mathrm{SO}_{4}-\mathrm{H}_{2} \mathrm{O}$ solutions. As is obvious in this figure, the water activities from the two sets of initial compositions of the test solutions chosen in different ways are in agreement with each other within the experimental error.

Figure $4 \sim 6$ show the activities of water determined in this work in terms of compositions of test solutions with the same water activity for the solution systems $\mathrm{H}_{2} \mathrm{SO}_{4}-\mathrm{MgSO}_{4}-$ $\mathrm{H}_{2} \mathrm{O}, \mathrm{H}_{2} \mathrm{SO}_{4}-\mathrm{Na}_{2} \mathrm{SO}_{4}-\mathrm{H}_{2} \mathrm{O}$ and $\mathrm{H}_{2} \mathrm{SO}_{4}-\mathrm{Li}_{2} \mathrm{SO}_{4}-$ $\mathrm{H}_{2} \mathrm{O}$, respectively, at $298 \mathrm{~K}$.

\section{Discussion}

Zdanovskii ${ }^{\text {j) }}$ discussed the empirical rule that linear or approximately linear relationships exist

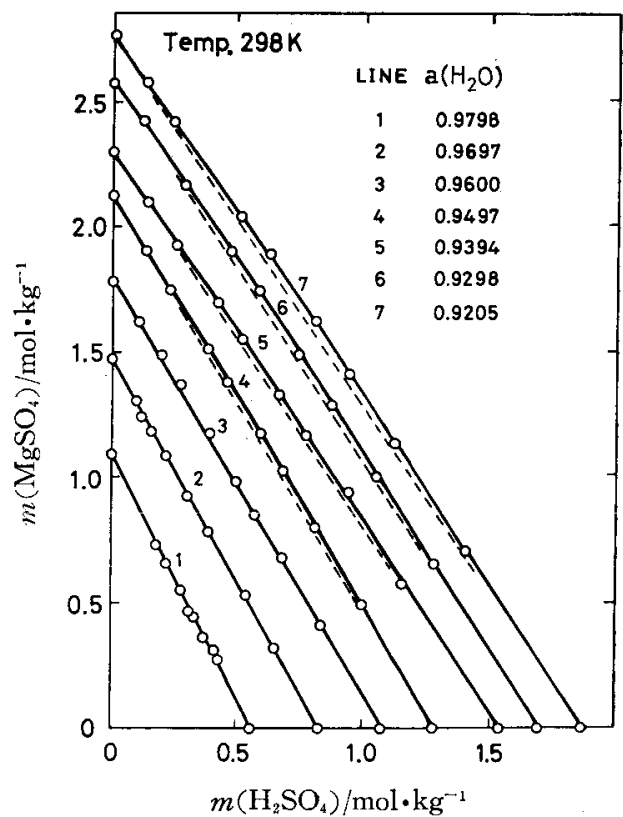

Fig. 4 Relationship between the molalities of sulfuric acid and sulfate under the condition of isopiestic equilibrium for the solution system $\mathrm{H}_{2} \mathrm{SO}_{4}-\mathrm{MgSO}_{4}-\mathrm{H}_{2} \mathrm{O}$ at $298 \mathrm{~K}$

(Dotted lines were calculated from Zdanovskii rule)

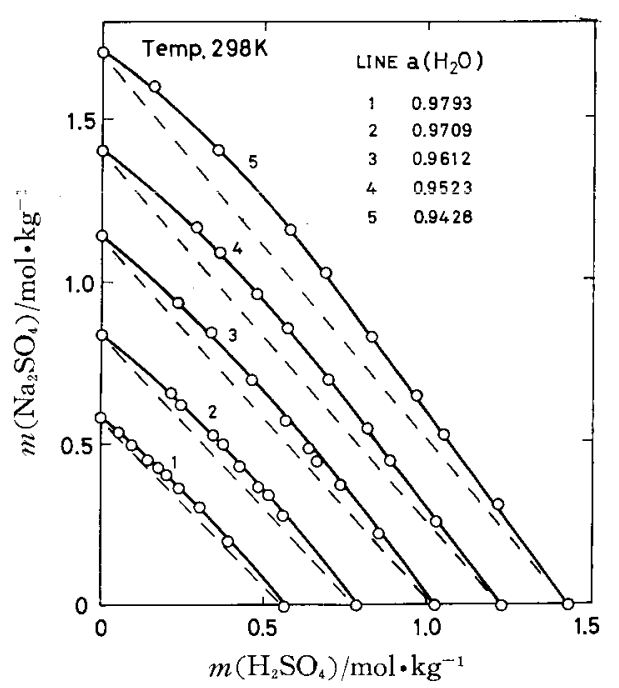

Fig. 5 Relationship between the molalities of sulfuric acid and sulfate under the condition of isopiestic equilibrium for the solution system $\mathrm{H}_{2} \mathrm{SO}_{4}-\mathrm{Na}_{2} \mathrm{SO}_{4}-\mathrm{H}_{2} \mathrm{O}$ at $298 \mathrm{~K}$

(Dotted lines were calculated from Zdanovskii rule)

between the molalities of electrolytes in solutions under the condition of isopiestic equili- 


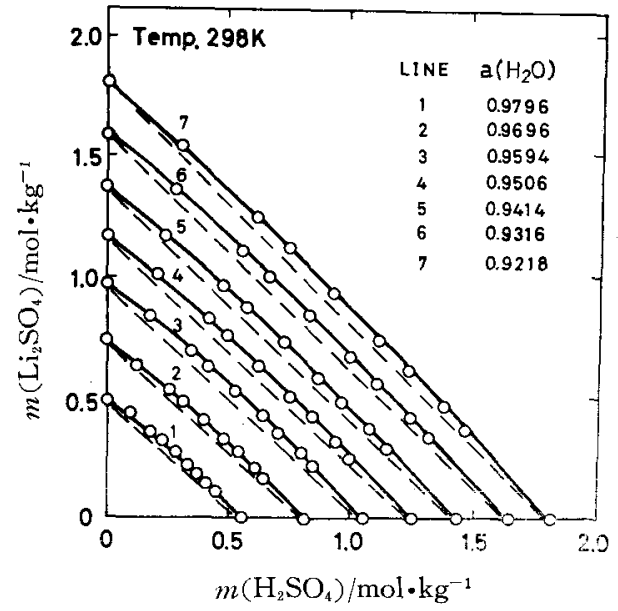

Fig. 6 Relationship between the molalities of sulfuric acid and sulfate under the condition of isopiestic equilibrium for the solution system $\mathrm{H}_{2} \mathrm{SO}_{4}-\mathrm{Li}_{2} \mathrm{SO}_{4}-\mathrm{H}_{2} \mathrm{O}$ at $298 \mathrm{~K}$

(Dotted lines were calculated from Zdanovskii rule)

brium; given a ternary aqueous solution of electrolyte 1 and electrolyte 2 at a total molality $m=m_{1}+m_{2}$ at isopiestic equilibrium with two binary solutions of molalities $m_{01}$ and $m_{02}$, then

$$
1 / m=y_{1} / m_{01}+y_{2} / m_{02}
$$

where $y_{1}=m_{1 /}^{\prime}\left(m_{1}+m_{2}\right)$ and $y_{2}=m_{2} /\left(m_{1}+m_{2}\right)$. Mikhailov $\left.{ }^{6}\right)$ rationalized equation (1) on the basis of the Debye-Hückel theory.

By rearranging equation (1), we can derive equation (2) at constant $a\left(\mathrm{H}_{2} \mathrm{O}\right)$, as reported by Zdanovskiii ${ }^{\text {s) }}$ and Stokes and Robinson ${ }^{i)}$.

$$
m_{1} / m_{02} \div m_{2} / m_{02}=1
$$

The dotted linear lines in Figs. $4 \sim 6$ are caluculated by means of this equation (2). Equation (2) is applicable to semi-ideal solutions of non-electrolytes at isopiestic equilibrium. Semiideality is defined to mean that solute-solute interactions are either mutually self-cancelling or negligible as compared with solute-solvent interactions. Departures from semi-ideality will be reflected as deviations from equation (2).

Another method of predicting $a\left(\mathrm{H}_{2} \mathrm{O}\right)$, more accurately, is the use of the corrected isopiestic relationship, which was originally presented by Kirgintsev and Lukyanov ${ }^{4}$. This relationship is given by equation (3):

$$
1 /\left(m_{1}+m_{2}\right)=y_{1} / m_{01}+y_{2} / m_{02}+b \cdot y_{1} \cdot y_{2} \quad \text { (3) }
$$

where $b$ is a parameter relating to the deviation from the Zdanovskii linearity. In general, however, $b$ itself is a function of water activity and is only available when the data for the ternary system have already been determined.

Chen and his coworkers ${ }^{8)}$ surveyed the Zdanovskii linearlity of 116 ternary aqueous systems. They divided these ternary systems into Groups $\mathrm{A}, \mathrm{B}$ and $\mathrm{C}$, according to the magnitudes of their average deviations from the Zdanovskii linearlity, $b(\mathrm{av})$, calculated from equation (2). The values of $b$ (av) for Group A are smaller than $0.02 \mathrm{~mol} \cdot \mathrm{kg}^{-1}$, and those for Group $\mathrm{C}$ are larger than $0.1 \mathrm{~mol} \cdot \mathrm{kg}^{-1}$. Group B includes the systems having $b$ (av) values $(0.02$ to $0.1 \mathrm{~mol}$. $\left.\mathrm{kg}^{-\mathrm{i}}\right)$. The values of $b(\mathrm{av})$ calculated for the solution systems presently studied are as follows: $0.039 \mathrm{~mol} \cdot \mathrm{kg}^{-1}$ for $\mathrm{H}_{2} \mathrm{SO}_{4}-\mathrm{MgSO}_{4}-\mathrm{H}_{2} \mathrm{O}, 0.240$ $\mathrm{mol} \cdot \mathrm{kg}^{-1}$ for $\mathrm{H}_{2} \mathrm{SO}_{4}-\mathrm{Na}_{2} \mathrm{SO}_{4}-\mathrm{H}_{2} \mathrm{O}$ and 0.122 $\mathrm{mol} \cdot \mathrm{kg}^{-1}$ for $\mathrm{H}_{2} \mathrm{SO}_{4}-\mathrm{Li}_{2} \mathrm{SO}_{4}-\mathrm{H}_{2} \mathrm{O}$. Therefore, the $\mathrm{H}_{2} \mathrm{SO}_{4}-\mathrm{MgSO}_{4}$ aqueous solutions should be classified to Group $\mathrm{B}$, while $\mathrm{H}_{2} \mathrm{SO}_{4}-\mathrm{Na}_{2} \mathrm{SO}_{4}$ and $\mathrm{H}_{2} \mathrm{SO}_{4}-\mathrm{Li}_{2} \mathrm{SO}_{4}$ aqueous solutions belong to Group C.

On the other hand, Robinson and Bower" measured the vapour pressure depressions of aqueous solutions of high ionic strength containing two alkali metal and/or alkali earth metal chlorides. From the experimental results, they discussed an additivity rule for the vapour pressure lowering of aqueous solutions of mixed chlorides. In terms the prediction of water activity in a ternary system chloride (1)-chloride (2) $-\mathrm{H}_{2} \mathrm{O}$ at the ionic strength $\mathrm{I}$ from water activities in both binary systems chloride (1) $-\mathrm{H}_{2} \mathrm{O}$ and chloride (2) $-\mathrm{H}_{2} \mathrm{O}$ at the same ionic strength in this rule may be written in the form:

$$
\begin{aligned}
& 1-a\left(\mathrm{H}_{2} \mathrm{O}\right)=m_{1}\left[\left\{1-a_{1}\left(\mathrm{H}_{2} \mathrm{O}\right)\right\} / m_{1}(\mathrm{I})\right] \\
& \quad+m_{2}\left[\left\{1-a_{2}\left(\mathrm{H}_{2} \mathrm{O}\right)\right\} / m_{2}(\mathrm{I})\right]
\end{aligned}
$$

where $\mathrm{I}$ is the molality ionic strength of the mixed solution, $m_{1}$ and $m_{2}$ are molalities of components 1 and 2 in the ternary system, and $m_{1}(\mathrm{I}), m_{2}(\mathrm{I})$ and $a_{1}\left(\mathrm{H}_{2} \mathrm{O}\right), a_{2}\left(\mathrm{H}_{2} \mathrm{O}\right)$ are the molalities and water activities, respectively, of the binary systems of ionic strength I. In order to determine the water activities for the ternary system being studied, we must know the values of the water activities of the binary systems. In this study, the values of the water activities of the binary systems $\mathrm{H}_{2} \mathrm{SO}_{4}-\mathrm{H}_{2} \mathrm{O}$, $\mathrm{MgSO}_{4}-\mathrm{H}_{2} \mathrm{O}, \quad \mathrm{Na}_{2} \mathrm{SO}_{4}-\mathrm{H}_{2} \mathrm{O}$ and $\mathrm{Li}_{2} \mathrm{SO}_{4}-\mathrm{H}_{2} \mathrm{O}$ cited in the data book ${ }^{37}$ were used for the calculation. 
Based on the experimental results, the activities of water in sulfuric acid-sulfate aqueous solutions, whose $\mathrm{H}_{2} \mathrm{SO}_{4}$ molalities were $0.1,0.2$, 0.5 and $1.0 \mathrm{~mol} \cdot \mathrm{kg}^{-1}$, were estimated by an interpolation method. The $a\left(\mathrm{H}_{2} \mathrm{O}\right)$ values thus determined were compared with those calculated from the Robinson and Bower equation. The relationship between the activites of water and the molalities of sulfate for solution systems $\mathrm{H}_{2} \mathrm{SO}_{4}-\mathrm{MgSO}_{4}-\mathrm{H}_{2} \mathrm{O}, \mathrm{H}_{2} \mathrm{SO}_{4}-\mathrm{Na}_{2} \mathrm{SO}_{4}-\mathrm{H}_{2} \mathrm{O}$ and $\mathrm{H}_{2} \mathrm{SO}_{4}-\mathrm{Li}_{2} \mathrm{SO}_{4}-\mathrm{H}_{2} \mathrm{O}$ are presented in Figs. $7 \sim 9$, respectively. In these calculations of the $a\left(\mathrm{H}_{2}\right.$ $\mathrm{O})$, we assumed for simplicity that both the first and second dissociations of sulfuric acid are complete.

The agreement between the values of the water activities determined by the isopiestic method and those calculated from the Robinson and Bower equation is satisfactory, showing a $0.2 \%$ deviation between them, although it is noted that the calculated values of the water activity show larger deviations from those determined experimentally at higher sulfate molalities. These findings suggest that the Robinson and Bower equation is useful to estimate the water activities for the solution system sulfuric acid-sulfate-water. Since hydrogen sulfate ion is indeed a relatively weak acid, it would be more reasonable to take account of this fact in the calculation of the water activities by means of the Robinson and Bower equation. The dis-

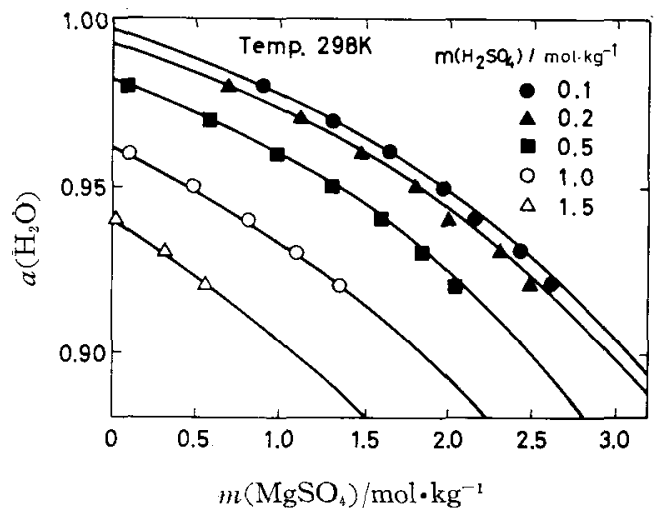

Fig. 7 Effect of the concentration of $\mathrm{MgSO}_{4}$ on the activity of water for the solution system $\mathrm{H}_{2} \mathrm{SO}_{4}-\mathrm{MgSO}_{4}-\mathrm{H}_{2} \mathrm{O}$ at $298 \mathrm{~K}$

(Solid lines were calculated from the Robinson and Bower equation assuming complete dissociation of sulfuric acid)

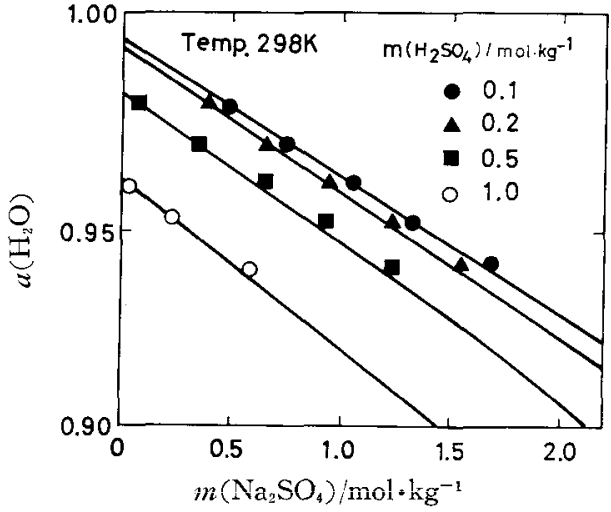

Fig. 8 Effect of the concentration of $\mathrm{Na}_{2} \mathrm{SO}_{4}$ on the activity of water for the solution system $\mathrm{H}_{2} \mathrm{SO}_{4}-\mathrm{Na}_{2} \mathrm{SO}_{4}-\mathrm{H}_{2} \mathrm{O}$ at $298 \mathrm{~K}$

(Solid lines were calculated from the Robinson and Bower equation assuming complete dissociation of sulfuric acid)

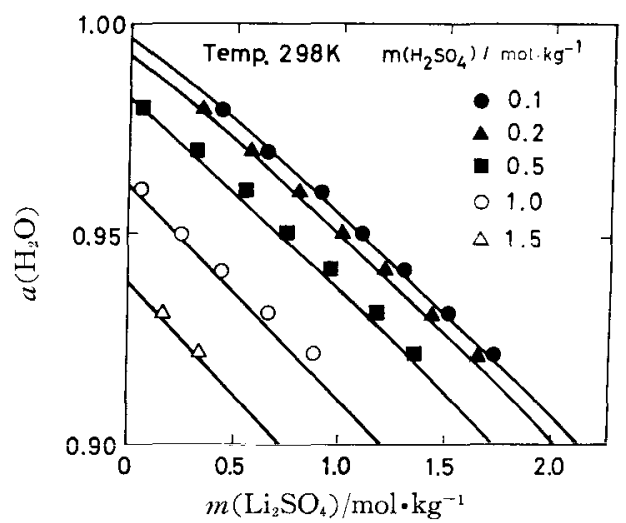

Fig. 9 Effect of the concentration of $\mathrm{Li}_{2} \mathrm{SO}_{4}$ on the activity of water for the solution system $\mathrm{H}_{2} \mathrm{SO}_{4}-\mathrm{Li}_{2} \mathrm{SO}_{4}-\mathrm{H}_{2} \mathrm{O}$ at $298 \mathrm{~K}$

(Solid lines were calculated from the Robinson and Bower equation assuming complete dissociation of sulfuric acid)

sociation of the hydrogen sulfate ion can be expressed by equation (5) as a function of ionic strength, I on the molality ${ }^{103}$ :

$$
\begin{gathered}
\log \begin{array}{c}
{\left[\mathrm{H}^{+}\right] \cdot\left[\mathrm{SO}^{2-}\right]} \\
{\left[\mathrm{HSO}_{4}{ }^{-}\right]}
\end{array}=\log (0.0102) \\
+\frac{2.036 \sqrt{I} / \mathrm{mol} \cdot \overline{\mathrm{kg}^{-1}}}{1+0.4 \sqrt{I / \mathrm{mol} \cdot \mathrm{kg}^{-1}}}
\end{gathered}
$$

where $\left[\mathrm{H}^{+}\right],\left[\mathrm{SO}_{4}{ }^{2-}\right]$ and $\left[\mathrm{HSO}_{4}{ }^{-}\right]$are the molalities of $\mathrm{H}^{+}, \mathrm{SO}_{4}{ }^{2-}$ and $\mathrm{HSO}_{4}^{-}$ions, respectively. On the other hand, the ionic strength of the test solution and the mass balance equations are given by equations (6), (7) and (8), 
respectively :

$$
\begin{aligned}
I= & \frac{1}{2}\left[\mathrm{H}^{+}\right]+\frac{1}{2}\left[\mathrm{HSO}_{4}{ }^{-}\right]+2\left[\mathrm{SO}_{4}{ }^{2-}\right] \\
& +z \cdot m\left(\mathrm{MSO}_{4}\right) \\
& {\left[\mathrm{H}^{+}\right]+\left[\mathrm{HSO}_{4}{ }^{-}\right]=2 m\left(\mathrm{H}_{2} \mathrm{SO}_{4}\right) } \\
& {\left[\mathrm{HSO}_{4}{ }^{-}\right]+\left[\mathrm{SO}_{4}{ }^{2-}\right]=m\left(\mathrm{H}_{2} \mathrm{SO}_{4}\right) } \\
& +m\left(\mathrm{MSO}_{4}\right)
\end{aligned}
$$

where $z$ is the change number of the metal ion originated from the sulfate, $\mathrm{MSO}_{4}$, and $m\left(\mathrm{H}_{2}\right.$ $\left.\mathrm{SO}_{4}\right)$ and $m\left(\mathrm{MSO}_{4}\right)$ are the molalities of sulfuric acid and sulfate, respectively. These simultaneous equations were solved by using a successive approximation method. With the calculated values of the ionic strength of each solutions, the values of $m_{1}(\mathrm{I})$ and $m_{2}(\mathrm{I})$ to be inserted into equation (4) are obtained by using a similar method.

The values of water activity determined by taking the dissociation constant of hydrogen sulfate ion into consideration are examplified typically for $\mathrm{H}_{2} \mathrm{SO}_{4}-\mathrm{MgSO}_{4}-\mathrm{H}_{2} \mathrm{O}$ in Fig. 10. As can

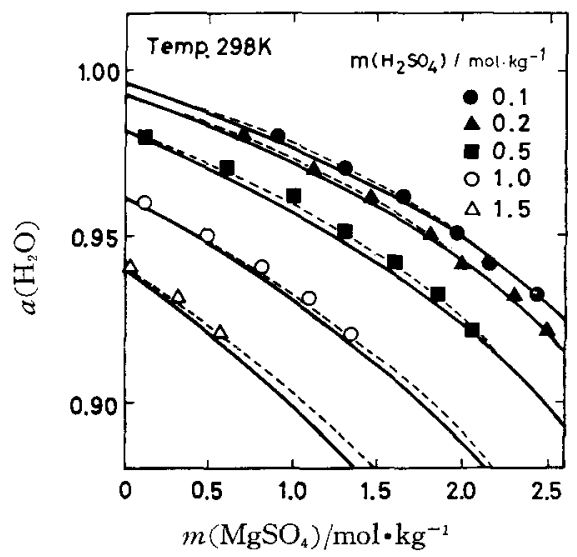

Fig. 10 Effect of the concentration of $\mathrm{MgSO}_{4}$ on the activity of water for the solution system $\mathrm{H}_{2} \mathrm{SO}_{4}-\mathrm{MgSO}_{4}-\mathrm{H}_{2} \mathrm{O}$ at $298 \mathrm{~K}$

(Solid lines were calculated from the Robinson and Bower equation considering the dissociation equilibrium of $\mathrm{HSO}_{4}^{-}$ions, while dotted lines were calculated assuming the complete dissociation of $\mathrm{H}_{2} \mathrm{SO}_{4}$ )

be seen, the deviation of the calculated values from the experimental values is more pronounced than that shown in Fig. 7. In this paticular case, the values thus calculated are a few percent lower than those determined experimentally. A similar tendency was observed for both of the solution systems $\mathrm{H}_{2} \mathrm{SO}_{4}-\mathrm{Na}_{2} \mathrm{SO}_{4}-\mathrm{H}_{2} \mathrm{O}$ and $\mathrm{H}_{2} \mathrm{SO}_{4}-\mathrm{Li}_{2} \mathrm{SO}_{4}-\mathrm{H}_{2} \mathrm{O}$. The relationship between the dissociation constant of the hydrogen sulfate ion and the ionic strength of the solution, represented by equation (5), was obtained originally for sulfuric acid solutions whose ionic strengths were below $5 \mathrm{~mol} \cdot \mathrm{kg}^{-1}$. It is questionable whether equation (5) can be applied to more concentrated solutions containing $\mathrm{Mg}^{2+}, \mathrm{Na}^{+}$or $\mathrm{Li}^{+}$ with an ionic strength of about $10 \mathrm{~mol} \cdot \mathrm{kg}^{-1}$. In fact, a different empirical reference relating the dissociation of hydrogen sulfate ion and the ionic strength of the solution was reported for the aqueous solution of $\mathrm{NH}_{4} \mathrm{HSO}_{4}$ and $\mathrm{NaHSO}_{4}$ with ionic strengths above $1 \mathrm{~mol} \cdot \mathrm{kg}^{-1},{ }^{10)}$ but a furhter discussion at this stage is avoided owing to the lack of experimental data on the dissociation of hydrogen sulfate ion on sulfuric acidsulfate-water solutions.

\section{Conclusions}

The activities of water were determined at $298 \mathrm{~K}$ by an isopiestic method for the solution systems: $\mathrm{H}_{2} \mathrm{SO}_{4}-\mathrm{MgSO}_{4}-\mathrm{H}_{2} \mathrm{O}, \mathrm{H}_{2} \mathrm{SO}_{4}-\mathrm{Na}_{2} \mathrm{SO}_{4}-$ $\mathrm{H}_{2} \mathrm{O}$ and $\mathrm{H}_{2} \mathrm{SO}_{4}-\mathrm{Li}_{2} \mathrm{SO}_{4}-\mathrm{H}_{2} \mathrm{O}$. It was found that the isopiestic method used in this work was reasonably accurate, showing only $0.3 \%$ error in $a\left(\mathrm{H}_{2} \mathrm{O}\right)$ values.

From the viewpoint of water activity, the $\mathrm{H}_{2} \mathrm{SO}_{4}-\mathrm{MgSO}_{4}-\mathrm{H}_{2} \mathrm{O}$ system belongs to Group $\mathrm{B}$ of the classification proposed by Chen et al., showing a slight deviation from the Zdanovskii rule. For the other two solution systems, the deviation from the Zdanovskii rule was more distinct, and they are to be calssified as Group C.

The applicability of the Robinson and Bower equation, which was originally derived for the estimation of water activity in mixed solutions of chlorides, to the present solution systems was also examined. By assuming complete dissociation of sulfuric acid, the $a\left(\mathrm{H}_{2} \mathrm{O}\right)$ values calculated by the Robinson and Bower equation show a satisfactory agreement with those obtained experimentally.

\section{Acknowledgments :}

Financial support by the Ministry of Education of Japan (Grant-in-Aid for Scientific Research No. 56470051) is gratefully acknowledged. The authors wish to express their thanks to Prof. R.E. Robins of the University of New South Wales, Australia, for his helpful discussion.

References: 
1) R.H. Stokes and R.A. Robinson, J. Am. Chem. Soc., 70, 1870 (1948).

2) S. Shankman and A.R. Gordon, J. Am. Chem. Soc., 61, 2370 (1939).

3) "Kagaku-Binran, Kiso-hen Part $\Pi$ ", ed. by Nihon Kagaku Kai, Maruzen, Tokyo, p. 747 (1975).

4) A.N. Kirgintsev and A.V. Lukyanov, Russ. J. Phys. Chem., 40, 957 (1966).

5) A.B. Zdanovskii, Trudy Solyanoi Laboratorii Akad. Nauk USSR, No. 6 (1936).
6) V.A. Mikhailov, Russ. J. Phys. Chem., 42, 1414 (1969).

7) R.H. Stokes and R.A. Robinson, J. Phys. Chem., 70, 2126 (1966).

8) H. Chen, J. Sangster, T.T. Teng, and F. Lenzi, Can. J. Chem. Eng., 51, 234 (1973).

9) R.A. Robinson and V.E. Bower, J. Res. Nat. Bur. Stand., 69 A, 365 (1965).

10) C.F. Baes, J. Am. Chem. Soc., 79, 5611 (1957).

(Received Jun. 26, 1982; Accepted Dec. 16, 1982)

\begin{tabular}{|c|c|}
\hline バイオマスエネルギー変換 & $\begin{array}{l}\text { えられて招り，これから学ぶ人のためにモデルの物理的 } \\
\text { 意味がわかりやすく表現されている。 }\end{array}$ \\
\hline 鈴木周一編 講談社発行 & （東京農工大学工学部資源応用化学科 小山 昇） \\
\hline $\begin{array}{l}\text { 本書は, バイオマスをエネルギー源として利用するバ } \\
\text { イオテクノロジーに関するものであり，エネルギー変換 } \\
\text { システムの原理から最近の話題をで調和よく取り上げら }\end{array}$ & $\begin{array}{l}\text { "Electrophoresis" Part B : Applications } \\
\text { (Elsevier) }\end{array}$ \\
\hline れまとめられている. バイオマスからのアルコール，メ & Ed. Z. Deyl, Co-ed. A. Chrambach, F.M. \\
\hline $\begin{array}{l}\text { タンおよび水素の生産, またクロロフィル電極や微生物 } \\
\text { 電池の可能性など, 分子生物学, 酵素工学および電気化 }\end{array}$ & Everaerts \& Z. Prusik, Elsevier Scientific \\
\hline 学などの学際領域にお污最新の内容が包括されてお & 本書は，1979年に刊行されたA部に続くもので，タン \\
\hline り, 異なる専門分野を集大成した優れた成書と考えられ & パク質, ペプチドなどの主要物質, 天然物質などへの電 \\
\hline る. （東京農工大学工学部資源応用化学科 小山 昇） & $\begin{array}{l}\text { 気泳動分離法の応用技術が詳述されている. 本書の特徴 } \\
\text { は，化合物ごとに電気泳動分離法の適用が述べられてお }\end{array}$ \\
\hline 液体の構造と物性 & $\begin{array}{l}\text { り，また最新の情報が系統的に整理網羅されており，読 } \\
\text { みやすく，使いやすい点である. 電気化学者はもちろ }\end{array}$ \\
\hline $\begin{array}{r}\text { D.H. Trevena 著, 田中 } \begin{array}{r}\text { 海 ・村田好正訳 } \\
\text { 共立出版発行 }\end{array}\end{array}$ & $\begin{array}{l}\text { ん, 有機㧍よび分析化学者, 薬学, 生化学㧍よび生医学 } \\
\text { などの研究に携わっている人にとって必読の書であり, }\end{array}$ \\
\hline 本書は，液相の本質を解明するための入門解説書とし & またこれから電気泳動法の技術を身につけたいと願って \\
\hline $\begin{array}{l}\text { て書かれている．全体をとおして分子論的立場からのと } \\
\text { らえ方が強調されているが，数式的表現はできるだけ押 }\end{array}$ & $\begin{array}{l}\text { いる人にとっての優れた参照本である. } \\
\text { (東京農工大学工学部資源応用化学科，小山 显) }\end{array}$ \\
\hline
\end{tabular}

